\title{
DEMAND ASSESSMENT OF MULTI LEVEL CAR PARKING IN
}

\section{GARUDA MALL}

\author{
M R Rajashekara', Mohammed Kalandar Khan', Nikita Anil Moodi ${ }^{3}$ \\ ${ }^{1}$ Professor Head, Civil Engineering, Dayananda Sagar Institute, Karnataka, India \\ ${ }^{2}$ Transport Planner, Volume Solutions Pvt Limited, Karnataka, India \\ ${ }^{3}$ Nikita Anil Moodi, Civil Engineering, Dayananda Sagar Institute, Karnataka, India
}

\begin{abstract}
There are more than 45 Lakh vehicles registered in Bengaluru as for 2014 and may likely go up to 50 lakh by 2015. Increasing parking demand together with limited parking space availability and the absence of a parking regulation is an impediment to the smooth flow of traffic, especially in and around the major commercial areas. The main objective of parking is to make an assessment of already existing shopping complex. The present study is also intended to evaluate the parking patterns, identifying authorized and unauthorized parking around the study area. There are several Multilevel Car Parking (MLCP) in the city but they are not fully utilized even population of vehicle is very high. here is a need to study the popularity of these parking spaces even though they are located in important places. Garuda Mall MLCP location was considered for the study.
\end{abstract}

Keywords: MLCP, Parking Issues, Annual Growth

\section{INTRODUCTION}

The number of motorized vehicles has been on an increase in Bengaluru. The annual growth rate of vehicles at $10 \%$ per annum is more than the growth rate of population which is $3 \%$. Many city roads are already suffering from congestion. The problem of congestion is compounded by the fact that parking is free in Bengaluru and on-street parking is unregulated. As a result, parked vehicles take up precious road space leaving less road space for moving vehicles. Parking, both on-street and off-street occupies valuable urban land.

\section{LITERATURE REVIEW}

\subsection{Parking issues-Bengaluru: An Overview}

The Parking issues of Bangalore are intricately related to the city structure, Infrastructure, traffic and management. The various parking issues on Bangalore have been defined as follows:

i. The One way system proposed for speedy movement within the city and streamlining the traffic had facilitated clear carriageways with removal of parking from the roads. These have resulted in moving the "on street parking" to the other roads and spaces available surrounding to these roads.

ii. The practice of "Pay and Park "has been tried for a few years for about 71 locations, this has been discarded since 2005. Though the Pay and Park has been discarded, this has resulted in the haphazard and unregulated parking, often some illegal collection of fee for parking.

\subsection{Site Reconnaissance Survey}

In order to understand the site, a site reconnaissance survey is essential. This survey was done for the study area to capture the road characteristics like available ROW and carriageway width. Land use in the site vicinity was surveyed.

\subsection{On-street and Off Parking Survey}

On-street parking surveys are intended to collect the extent of usage of parking facilities along the roadside. The survey has been conducted by counting the vehicles parked on the road at regular time intervals for a particular duration of the day.

\section{CASE STUDY: GARUDA MALL}

\subsection{Study Area and Site Plan}

The site is located on the corner of Magrath Road and Commissariat Road junction under Ashok Nagar limits in the north south direction making it a North - East corner. The site area is estimated to be 14814 sqmt and the site in a broad sense is located in a predominantly profitable locality where the commercial activity is intense. Towards the Southern side of the site is Wesley Church opposite of which is the foot ball stadium. North of Garuda Mall is the Police officers ground and to the west is the 2 nd cross road with mixed land use.

Zone 1: Part of Magrath road, Brigade road, Residency road.

Zone 2: Commissariat road, Primrose road, some part of Magrath road, Brunton road and Brunton cross road

Zone 3: Part of Magrath road, part of Richmond road, Victoria road. 
Zone 4: Museum road, Mother Teresa road, part of Richmond road, Bowee Ln street, wood street, Castle street, part of Brigade road.

\section{DATA COLLECTION AND ANALYSIS}

\subsection{Parking Supply}

Two types of on-street parking, parallel, and angular are prevailing in the study area. In on-street parking, vehicles are parked on the street. They may be authorized parking stretches as well as stretches where parking is prohibited but still parking is observed.

Table 1 Parking volume

\begin{tabular}{|l|l|l|l|l|l|}
\hline \multicolumn{3}{|l|}{$\begin{array}{l}\text { Total Accumulation of Parked } \\
\text { vehicles on street }\end{array}$} & \multicolumn{2}{|l|}{$\begin{array}{l}\text { Total } \\
\text { Accumulation of } \\
\text { Parked vehicles } \\
\text { off street }\end{array}$} \\
\hline Zones & $\begin{array}{l}\text { Weekd } \\
\text { ay }\end{array}$ & $\begin{array}{l}\text { weeken } \\
\text { d }\end{array}$ & $\begin{array}{l}\text { Chan } \\
\text { ge \% }\end{array}$ & $\begin{array}{l}\text { weekd } \\
\text { ay }\end{array}$ & $\begin{array}{l}\text { Weeken } \\
\text { d }\end{array}$ \\
\hline Zone 1 & 670 & 480 & 28.35 & 15 & 18 \\
\hline Zone 2 & 149 & 65 & 56.37 & - & - \\
\hline Zone 3 & 240 & 105 & 56.25 & 90 & 25 \\
\hline Zone 4 & 357 & 286 & 19.88 & - & - \\
\hline $\begin{array}{l}\text { TOTA } \\
\text { L }\end{array}$ & 1461 & 936 & 33.89 & 105 & 43 \\
\hline
\end{tabular}

\subsection{Parking Volume - zone wise}

The total number of vehicles parked in an area at a particular time was counted i.e. the accumulation surveys were done for all Zones, for weekdays and weekend the result is given inTable 2 and Table 3.

Table 2: Cars Turn Over at Garuda Mall during Summer Holidays

\begin{tabular}{|l|l|l|l|l|}
\hline Day & $\begin{array}{l}\text { Cars } \\
\text { turnov } \\
\text { er }\end{array}$ & $\begin{array}{l}\text { TW } \\
\text { turnover(E } \\
\text { CS) }\end{array}$ & $\begin{array}{l}\text { AUTO(E } \\
\text { CS) }\end{array}$ & $\begin{array}{l}\text { Round } \\
\text { ed } \\
\text { off(EC } \\
\text { S) }\end{array}$ \\
\hline Monday & 1006 & 994 & 29 & 1280 \\
\hline Tuesday & 993 & 811 & 35 & 1220 \\
\hline $\begin{array}{l}\text { Wednesd } \\
\text { ay }\end{array}$ & 996 & 1050 & 41 & 1291 \\
\hline $\begin{array}{l}\text { Thursda } \\
\text { y }\end{array}$ & 995 & 967 & 40 & 1267 \\
\hline Friday & 1217 & 891 & 48 & 1513 \\
\hline Saturday & 2151 & 1803 & 96 & 2674 \\
\hline Sunday & 2183 & 1766 & 30 & 2650 \\
\hline
\end{tabular}

Table 3 Peak hour and off-peak parking Demand and Supply Gap at Garuda Mall

\begin{tabular}{|l|l|l|l|l|l|l|}
\hline & \multicolumn{2}{|l|}{$\begin{array}{l}\text { Peak } \\
\text { (ECS) }\end{array}$} & Hour & \multicolumn{2}{|l|}{$\begin{array}{l}\text { Off-peak } \\
\text { Hour (ECS) }\end{array}$} & Gap \\
\hline Day & $\begin{array}{l}\text { Dema } \\
\text { nd }\end{array}$ & $\begin{array}{l}\text { Supp } \\
\text { ly }\end{array}$ & $\begin{array}{l}\text { Volu } \\
\text { me }\end{array}$ & $\begin{array}{l}\text { Dema } \\
\text { nd }\end{array}$ & $\begin{array}{l}\text { Supp } \\
\text { ly }\end{array}$ & $\begin{array}{l}\text { Volu } \\
\text { me }\end{array}$ \\
\hline Monday & 176 & 972 & 796 & 56 & 972 & 916 \\
\hline
\end{tabular}

\begin{tabular}{|l|l|l|l|l|l|l|} 
Tuesday & 167 & 972 & 804 & 84 & 972 & 888 \\
\hline $\begin{array}{l}\text { Wednes } \\
\text { day }\end{array}$ & 187 & 972 & 785 & 90 & 972 & 882 \\
\hline Thursdy & 123 & 972 & 849 & 85 & 972 & 887 \\
\hline Friday & 125 & 972 & 847 & 67 & 972 & 905 \\
\hline Saturdy & 261 & 972 & 712 & 123 & 972 & 849 \\
\hline Sunday & 399 & 972 & 573 & 220 & 972 & 752 \\
\hline
\end{tabular}

\subsection{Parking Demand and Supply Gap}

Peak parking demand and supply observed at Garuda Mall MLCP is from the primary parking surveys as given in Table 3. Supply is calculated on the basis of parking norms and available type of parking style.

It is observed that during the weekdays the average total gap between supply and demand is about 849 ECS and during the weekends the average gap is about 573 during the peak hours. Similarly the off-peak demand during the weekdays is 85 and weekend is 752. This shows that at any given time the parking slots at Garuda Mall are underutilized i.e. slots are vacant.

The total day's parking turnover was also done for 8 days from Sunday to Sunday to know the actual turn over at the Garuda Mall MLCP. The Total variation of the week can be obtained and the flow pattern of the parking can be known. The details are as shown in Table 4 below.

Table 4 ParkingVariation over at Garuda Mall

\begin{tabular}{|c|c|c|c|c|}
\hline Day & $\begin{array}{l}\text { Cars } \\
\text { turnov } \\
\text { er } \\
\end{array}$ & $\begin{array}{l}\text { TW } \\
\text { turnover(E } \\
\text { CS) }\end{array}$ & $\begin{array}{l}\text { AUTO(EC } \\
\text { S) }\end{array}$ & $\begin{array}{l}\text { Round } \\
\text { ed } \\
\text { off(EC } \\
\text { S) } \\
\end{array}$ \\
\hline Monday & 708 & 292 & 29 & 796 \\
\hline Tuesday & 647 & 496 & 35 & 790 \\
\hline $\begin{array}{l}\text { Wednesd } \\
\text { ay }\end{array}$ & 599 & 304 & 41 & 772 \\
\hline Thursday & 474 & 284 & 40 & 565 \\
\hline Friday & 670 & 380 & 48 & 790 \\
\hline Saturday & 1003 & 672 & 96 & 1220 \\
\hline Sunday & 1206 & 736 & 30 & 1410 \\
\hline
\end{tabular}

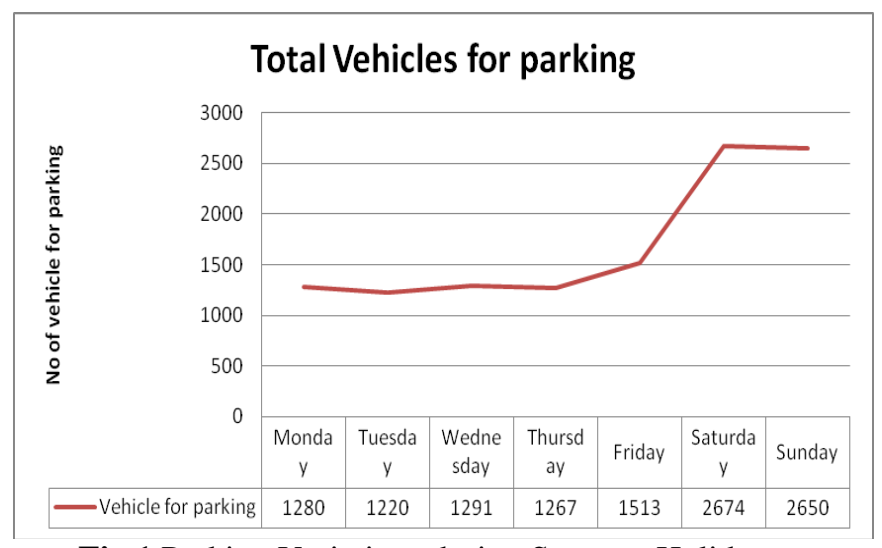

Fig 1 Parking Variations during Summer Holidays 


\section{TRAFFIC VOLUMES COUNTS SURVEY}

Turning Movement volume counts was conducted on two Locations weekdays and one weekend near LIFESTYLE, Garuda Mall. The traffic volume counts were conducted for every 15 minutes interval starting from peak hour 9.00 AM to $12.00 \mathrm{PM}$ and 4.PM to 8PM. The peak hour traffic flow was found to be between 15.30 PM to 16.30 PM. The highest traffic has been observed on commissiorait road, the traffic volume summary is shown in Tables

Table 5 Traffic Volume Summary-Weekday

\begin{tabular}{|l|l|l|l|l|l|}
\hline & $\begin{array}{l}\text { Total } \\
\text { Volume } \\
\text { (Vehicl } \\
\text { L) }\end{array}$ & $\begin{array}{l}\text { Total } \\
\text { PCU }\end{array}$ & $\begin{array}{l}\text { Peak } \\
\text { Hour } \\
\text { (Vehicle } \\
\text { s) }\end{array}$ & $\begin{array}{l}\text { Peak } \\
\text { Hour } \\
\text { (PCU } \\
\text { ) }\end{array}$ & $\begin{array}{l}\text { Peak } \\
\text { Hour } \\
\text { (PCU) }\end{array}$ \\
\hline $\begin{array}{l}\text { LIFESTYL } \\
\text { E }\end{array}$ & 59317 & $\begin{array}{l}6761 \\
9\end{array}$ & 8459 & 9816 & $14.5 \%$ \\
\hline $\begin{array}{l}\text { Garuda } \\
\text { Mall }\end{array}$ & 41905 & $\begin{array}{l}4975 \\
5\end{array}$ & 7076 & 7807 & $15.7 \%$ \\
\hline Mid block & 20285 & $\begin{array}{l}2457 \\
5\end{array}$ & 3308 & 3985 & $\begin{array}{l}16.21 \\
\%\end{array}$ \\
\hline
\end{tabular}

Table 6 Traffic Volume Summary-Weekend

\begin{tabular}{|l|l|l|l|l|l|}
\hline Location & $\begin{array}{l}\text { Total } \\
\text { Volume } \\
(\text { Vehicle) }\end{array}$ & $\begin{array}{l}\text { Total } \\
\text { PCU }\end{array}$ & $\begin{array}{l}\text { Peak } \\
\text { Hour } \\
\text { (Vehicles) }\end{array}$ & $\begin{array}{l}\text { Peak } \\
\text { Hour } \\
\text { (PCU) }\end{array}$ & $\begin{array}{l}\% \\
\text { Peak } \\
\text { Hour } \\
\text { (PCU) }\end{array}$ \\
\hline LIFESTYLE & 41604 & 50376 & 6863 & 7945 & $15.9 \%$ \\
\hline Garuda Mall & 25734 & 34016 & 4687 & 5478 & $16.1 \%$ \\
\hline Midblock & 15488 & 19879 & 2432 & 3079 & $15.5 \%$ \\
\hline
\end{tabular}

\subsection{Opinion Surveys}

This section of the report elucidates the opinion of the user regarding parking problems faced by them, parking rates prevailing in the area, future parking charge system and parking fee to be charged. Opinion about willingness to pay for parking facilities, trip purpose, trip frequency, comfort level etc was collected from both car users and non-car users. Car owners are those coming in cars, while non-car users are those who are coming in other modes which include two-wheelers, bus, by walk, etc. Opinion survey results are useful in deciding the parking charge system, parking fee etc. Total of 100 samples were done in and around the Garuda Mall.

\section{FUTURE CONDITIONS}

\subsection{Estimation of Parking Demand}

This section estimates the future parking demand for the area and assesses whether the site can handle the unattended parking demand. The data regarding number of employees, built-up area etc and other base information for the study area, could not be collected adequately by the survey teams due to security restrictions during the course of the surveys at study Sites. It was the sheer reluctance of the local people to part with information during the survey period that led a situation where desired data was unobtainable. In absence of sufficient data, future parking demand has been estimated as explained below.

\subsection{Parking Turnover rate / yield}

It is the number of vehicles utilizing the available ECS in a unit time (usually considered for the entire day)

The mathematical equation for future parking demand is as below.

Yield = Total observed Daily Turn Over / Peak hour parking demand..........1

Assumed yield here is the rounded value of the yield obtained from ..........1

Available Capacity $=$ Assumed Yield $\mathbf{x}$ Total parking supply available ........... 2

Future Parking demand $=$ Total Observed daily turnover $(1+\text { Vehicle Growth rate })^{\text {n }}$.......3

Represents the existing situation n- Number of years.

\section{Percentage of Parking Space availability = 1 - (ExistingobservedTurnover) \\ MaximumCapacityof MLCPw. r. texistingyield}

The following table summarizes the future parking demand.

Table 7: Future Parking Demand Estimation of Garuda Mall and the adjoining roads during weekdays

\begin{tabular}{|c|c|c|c|}
\hline $\begin{array}{l}\text { Sl } \\
\text { No }\end{array}$ & Details & $\begin{array}{l}\text { Garuda } \\
\text { Mall }\end{array}$ & $\begin{array}{l}\text { Adjoining } \\
\text { Roads }\end{array}$ \\
\hline 1 & Day & Weekday & Weekday \\
\hline 2 & $\begin{array}{l}\text { Peak hour Parking } \\
\text { Demand }\end{array}$ & $187 \mathrm{ECS}$ & $250 \mathrm{ECS}$ \\
\hline 3 & $\begin{array}{l}\text { Total Parking } \\
\text { supply available }\end{array}$ & 972 ECS & $100 \mathrm{ECS}$ \\
\hline 4 & $\begin{array}{lr}\text { Total observed } \\
\text { daily ECS Turnover }\end{array}$ & $708 \mathrm{ECS}$ & $375 \mathrm{ECS}$ \\
\hline 5 & $\begin{array}{l}\text { Forecasted ECS for } \\
\text { next } 5 \text { years }\end{array}$ & $\begin{array}{l}1254 \\
\mathrm{ECS}\end{array}$ & $600 \mathrm{ECS}$ \\
\hline 6 & Yield & 3.8 & 1.5 \\
\hline 7 & Assumed Yield & 4 & 1.5 \\
\hline 8 & $\begin{array}{l}\text { Maximum Capacity } \\
\text { of MLCP w.r.t } \\
\text { existing yield }\end{array}$ & $\begin{array}{l}3900 \\
\mathrm{ECS}\end{array}$ & $150 \mathrm{ECS}$ \\
\hline 9 & $\begin{array}{l}\text { Existing Parking } \\
\text { Demand .i.e. } 2014\end{array}$ & $708 \mathrm{ECS}$ & $375 \mathrm{ECS}$ \\
\hline 10 & $\begin{array}{l}\text { Percentage } \\
\text { unoccupied ECS } \\
\text { availability in the } \\
\text { year 2014 }\end{array}$ & $82 \%$ & ------- \\
\hline 11 & $\begin{array}{l}\text { Number of ECS } \\
\text { available for the } \\
\text { year 2014 } \\
\text { assumed yield }\end{array}$ & $796 \mathrm{ECS}$ & ------- \\
\hline
\end{tabular}




\begin{tabular}{|c|c|c|c|}
\hline 12 & $\begin{array}{l}\text { Percentage } \\
\text { availability of ECS } \\
\text { w.r.t to assumed } \\
\text { yield at MLCP in } \\
\text { the year 2014, when } \\
\text { the on street } \\
\text { parking in the } \\
\text { adjoining road is } \\
\text { shifted to Garuda } \\
\text { Mall MLCP }\end{array}$ & \multicolumn{2}{|c|}{$72 \%$.i.e. 702 ECS } \\
\hline 13 & $\begin{array}{l}\text { Impact } \\
\text { Weekdays in the } \\
\text { year 2014 }\end{array}$ & \multicolumn{2}{|c|}{$\begin{array}{l}\text { MLCP will have } \\
\text { Sufficient availability of } \\
\text { Parking space }\end{array}$} \\
\hline 14 & $\begin{array}{l}\text { Future Parking } \\
\text { Demand in the year } \\
2020 \text { at } 10 \% \\
\text { vehicle growth }\end{array}$ & $\begin{array}{l}1254 \\
\text { ECS }\end{array}$ & $600 \mathrm{ECS}$ \\
\hline 15 & $\begin{array}{l}\text { Percentage } \\
\text { unoccupied ECS } \\
\text { availability in the } \\
\text { year } 2020\end{array}$ & $68 \%$ & ------- \\
\hline 16 & $\begin{array}{l}\text { Number of ECS } \\
\text { available for the } \\
\text { year } 2020 \text { w.r.t } \\
\text { assumed yield and } \\
\text { estimated future } \\
\text { Parking Demand }\end{array}$ & $659 \mathrm{ECS}$ & -------- \\
\hline 17 & $\begin{array}{l}\text { Percentage } \\
\text { availability of ECS } \\
\text { w.r.t to assumed } \\
\text { yield at MLCP in } \\
\text { the year } 2020 \text { when } \\
\text { the on street } \\
\text { parking in the } \\
\text { adjoining road is } \\
\text { shifted to Garuda } \\
\text { Mall MLCP }\end{array}$ & \multicolumn{2}{|c|}{$52 \%$ i.e. 509 ECS } \\
\hline 18 & $\begin{array}{l}\text { Impact } \\
\text { Weekdays by the } \\
\text { year } 2020\end{array}$ & \multicolumn{2}{|c|}{$\begin{array}{l}\text { MLCP will still have } \\
\text { Sufficient availability of } \\
\text { Parking space }\end{array}$} \\
\hline 19 & $\begin{array}{l}\text { Future Parking } \\
\text { demand in the Year } \\
2025 \text { with } 10 \% \\
\text { vehicle growth }\end{array}$ & 2020 & 970 \\
\hline 20 & $\begin{array}{l}\text { Percentage } \\
\text { unoccupied ECS } \\
\text { availability in the } \\
\text { year } 2025 \text { value for } \\
10 \% \text { vehicle growth }\end{array}$ & $48 \%$ & \\
\hline 21 & 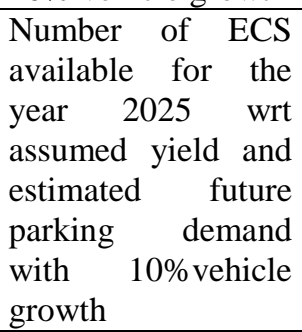 & $469 \mathrm{ECS}$ & \\
\hline 22 & $\begin{array}{l}\text { Percentage } \\
\text { availability of ECS } \\
\text { wrt assumed yield }\end{array}$ & $29 \%$ & \\
\hline
\end{tabular}

\begin{tabular}{|l|l|l|l|}
\hline & $\begin{array}{l}\text { at MLCP in the year } \\
2025 \text { when the on } \\
\text { street parking in the } \\
\text { adjoining road is } \\
\text { shifted to Garuda } \\
\text { Mall MLCP }\end{array}$ & & \\
\hline 23 & $\begin{array}{l}\text { Impact } \\
\text { Weekdays by the } \\
\text { year 2025 with 10\% } \\
\text { vehicle growth }\end{array}$ & $\begin{array}{l}\text { MLCP will } \\
\text { still have } \\
\text { sufficient } \\
\text { capacity }\end{array}$ \\
\hline
\end{tabular}

Thus it clearly shows that there is still enormous space available at the MLCP in the coming years during the weekdays.

Thus the UN authorised parking in the vicinity of Garuda Mall has to be shifted to the MLCP. This also increases the Revenue.

Table 8 Future Parking Demand Estimation of Garuda Mall and the adjoining roads during weekends

\begin{tabular}{|c|c|c|c|}
\hline $\begin{array}{l}\text { Sl } \\
\text { No }\end{array}$ & Details & $\begin{array}{l}\text { Garuda } \\
\text { Mall }\end{array}$ & $\begin{array}{l}\text { Adjoining } \\
\text { Roads }\end{array}$ \\
\hline 1 & Day & Weekend & Weekend \\
\hline 2 & $\begin{array}{l}\text { Peak hour Parking } \\
\text { Demand }\end{array}$ & $399 \mathrm{ECS}$ & $100 \mathrm{ECS}$ \\
\hline 3 & Parking supply available & $972 \mathrm{ECS}$ & $200 \mathrm{ECS}$ \\
\hline 4 & ECS Turnover & $\begin{array}{l}1206 \\
\text { ECS }\end{array}$ & $300 \mathrm{ECS}$ \\
\hline 5 & $\begin{array}{l}\text { Forecasted ECS for next } 5 \\
\text { years }\end{array}$ & $\begin{array}{l}2137 \\
\text { ECS }\end{array}$ & $480 \mathrm{ECS}$ \\
\hline 6 & Yield & 3 & 3 \\
\hline 7 & Assumed Yield & 3 & 3 \\
\hline 8 & $\begin{array}{l}\text { Maximum Capacity w.r.t } \\
\text { existing yield }\end{array}$ & $\begin{array}{l}1950 \\
\text { ECS }\end{array}$ & $600 \mathrm{ECS}$ \\
\hline 9 & $\begin{array}{l}\text { Existing Parking Demand } \\
\text {.i.e. } 2014\end{array}$ & $\begin{array}{l}1206 \\
\text { ECS }\end{array}$ & $100 \mathrm{ECS}$ \\
\hline 10 & $\begin{array}{l}\text { Percentage unoccupied } \\
\text { ECS availability in the } \\
\text { year } 2014\end{array}$ & $38 \%$ & $50 \%$ \\
\hline 11 & $\begin{array}{l}\text { Number of ECS available } \\
\text { for the year } 2014 \text { w.r.t } \\
\text { assumed yield }\end{array}$ & $371 \mathrm{ECS}$ & $100 \mathrm{ECS}$ \\
\hline 12 & $\begin{array}{l}\text { Percentage availability of } \\
\text { ECS w.r.t to assumed } \\
\text { yield at MLCP in the year } \\
2014 \text {, when the on street } \\
\text { parking in the adjoining } \\
\text { road is shifted to Garuda } \\
\text { Mall MLCP }\end{array}$ & \multicolumn{2}{|c|}{$23 \%$.i.e. $221 \mathrm{ECS}$} \\
\hline 13 & $\begin{array}{l}\text { Impact w.r.t weekends in } \\
\text { the year } 2014\end{array}$ & $\begin{array}{l}\text { MLCP } \\
\text { Sufficient } \\
\text { of Parking }\end{array}$ & $\begin{array}{l}\text { vill have } \\
\text { availability } \\
\text { pace }\end{array}$ \\
\hline
\end{tabular}




\begin{tabular}{|c|c|c|c|}
\hline 14 & $\begin{array}{l}\text { Future Parking Demand in } \\
\text { the year } 2020 \text { at } 10 \% \\
\text { vehicle growth }\end{array}$ & $\begin{array}{l}2137 \\
\text { ECS }\end{array}$ & $480 \mathrm{ECS}$ \\
\hline 15 & $\begin{array}{l}\text { Percentage unoccupied } \\
\text { ECS availability in the } \\
\text { year } 2020\end{array}$ & $\begin{array}{l}\text { (minus)- } \\
10 \%\end{array}$ & $19 \%$ \\
\hline 16 & $\begin{array}{l}\text { Number of ECS available } \\
\text { for the year } 2020 \text { w.r.t } \\
\text { assumed yield and } \\
\text { estimated future Parking } \\
\text { Demand }\end{array}$ & $\begin{array}{l}\text { (minus)- } \\
93 \text { ECS }\end{array}$ & $40 \mathrm{ECS}$ \\
\hline 17 & $\begin{array}{l}\text { Percentage availability of } \\
\text { ECS w.r.t to assumed } \\
\text { yield at MLCP in the year } \\
2020 \text { when the on street } \\
\text { parking in the adjoining } \\
\text { road is shifted to Garuda } \\
\text { Mall MLCP }\end{array}$ & \multicolumn{2}{|c|}{$\begin{array}{l}\text { (minus) }-3 \% \text {.i.e. } 27 \\
\text { ECS will be required }\end{array}$} \\
\hline 18 & $\begin{array}{l}\text { Impact w.r.t Weekdays by } \\
\text { the year } 2020\end{array}$ & \multicolumn{2}{|c|}{$\begin{array}{l}\text { MLCP will still have } \\
\text { slight spillover of } \\
\text { parking which can be } \\
\text { handled by enforcement } \\
\text { plans. }\end{array}$} \\
\hline 19 & $\begin{array}{l}\text { Future Parking Demand in } \\
\text { the year } 2025 \text { with } 10 \% \\
\text { vehicle growth }\end{array}$ & 3441 & 620 \\
\hline 20 & $\begin{array}{ll}\text { Percentage } & \text { ECS } \\
\text { availability in the year } \\
2025 \text { value with } 10 \% \\
\text { vehicle growth }\end{array}$ & $-76 \%$ & $-3 \%$ \\
\hline 21 & $\begin{array}{l}\text { Number of ECS available } \\
\text { for the year } 2025 \text { w.r.t } \\
\text { assumed yield and } \\
\text { estimated future Parking } \\
\text { Demand with } 10 \% \text { vehicle } \\
\text { growth }\end{array}$ & $\begin{array}{l}743 \text { ECS } \\
\text { will be } \\
\text { required }\end{array}$ & $\begin{array}{l}\text { (minus) }-6 \\
\text { ECS will } \\
\text { be required }\end{array}$ \\
\hline 22 & $\begin{array}{l}\text { Impact w.r.t Weekdays by } \\
\text { the year } 2025 \text { with } 10 \% \\
\text { vehicle growth }\end{array}$ & \multicolumn{2}{|c|}{$\begin{array}{l}\text { MLCP will have } \\
\text { sufficient space }\end{array}$} \\
\hline
\end{tabular}

For future estimation and projection of parking demand for weekend, at the site and the adjoining roads, it is observed that the yield at site is about 3.3 per ECS and 3 per ECS in the adjoining roads. The vehicle growth rate is assumed to be $10 \%$ till 2020 . The forecasted parking demand for the year 2020 at the site is 2137 ECS and 480 ECS at the adjoining roads.

Considering the current year's peak parking demand at the site with 2137 ECS and the supply of 972 ECS on a particular weekend, the availability of parking space is about $38 \%$ (.i.e. $280 \mathrm{ECS}$ ) and the forecasted space availability in the year 2020 and 2025 at the site will be(minus) - 10\%(.i.e. 100 ECS will be required).Hence the on- street parking shift is needed immediately from the adjoining roads into the MLCP.

\section{DISCUSSIONS AND CONCLUSIONS}

$>$ Current Year: As per the surveys and analysis, the capacity of the MLCP calculated based on current peak hour parking demand and the Average turnover of a week is 954 ECS. The analysis in the preceding chapter shows that the MLCP has got sufficient car parking space to cater the present parking demand.

$>$ Horizon Year 2020: At this parking demand and the shift of on-street parking into the MLCP, the MLCP will have sufficient parking spaces available during the weekdays

$>$ Horizon Year 2025: Considering the vehicle growth rate of $10 \%$ annually, the parking demand at MLCP in the year 2025 is most likely to be around 2020 ECS during the weekdays and 3441 ECS in the weekends.

\section{REFERENCES}

[1] Wilbur Smith Associates, Inc, "Development of Multilevel parking facilities in Greater Mumbai" , October 2008

[2] Directorate of Urban Land ,Policy Paper for Parking, In the Bangalore Metropolitan Region", Version 1 ,October 2008

[3] Bangalore Development Authority ,"Zoning of land use and regulations", Revised Master Plan ,Volume III ,2007

[4] Kadiyali,L.R, "Traffic Engineering and Transportation Planning” ,Khanna Publishers, Third Edition 2002.

[5] Khanna S. K \& Justo C.E.G, "Highway Engineering", Nem Chand \& Bros, Roorkee (U.A), Eighth Edition -2001

[6] National Urban Transport Policy for India, Ministry of Urban Development, Government of India, April 2006. 